\title{
Study on Utilization of Fly Ash Aggregates in Concrete
}

\author{
S. Shanmugasundaram \\ Assistant Professor/Civil, MPNMJ Engineering College, Chennimalai. - 638 112, India \\ Dr. S. Jayanthi \\ Assistant Professor/Civil, Thanthai Periyar Government Institute of Technology, Vellore - 632 002, India \\ Dr. R. Sundararajan \\ Principal, Government College of Technology, Coimbatore, India \\ Dr. C. Umarani \\ Assistant Professor/Civil, College of Engineering, Guindy, India \\ Dr. K. Jagadeesan \\ Principal, MPNMJ Engineering College, Chennimalai - 638 112, India
}

\begin{abstract}
In this study, the fine and coarse aggregates were completely replaced by fly ash aggregates in fly ash concrete. A mix design was done for M20 grade of concrete by IS method. Ordinary Portland cement of 43 grade was selected and fly ash aggregates were prepared by mixing fly ash with cement and water. The properties of fly ash fine aggregates and fly ash coarse aggregates were studied. The aggregate crushing value and aggregate impact value of fly ash coarse aggregates were also studied. The cement and fly ash proportions of 10:90, 12.5:87.5, $15: 85,17.5: 82.5,20: 80$ and 22.5:77.5 were tried with a suitable water cement ratio 0.3 to get the fly ash aggregates. The concrete cubes, cylinders and beams were cast with the fly ash aggregates obtained from the above six cement fly ash proportions. Then the compressive strength, split tensile strength and flexural strength were tested and compared with control concrete. This paper briefly presents the compressive strength development of fly ash aggregate concrete at different ages. The split tensile strength and flexural strength of all the concrete mixes were also investigated at different days of curing.
\end{abstract}

Keywords: Fly ash aggregates (FAA), Fly ash Fine Aggregates (FAFA), Fly ash Coarse Aggregate (FACA), Fly ash Aggregate Concrete (FAAC), Compressive Strength, Split tensile strength, Flexural strength, Control concrete (CC)

\section{Introduction}

In conventional concrete, weight of concrete is one of the parameters to compare with weight of fly ash aggregate concrete. Normally density of concrete is in the order of 2200 to $2600 \mathrm{~kg} / \mathrm{m}^{3}$. This heavy self weight makes an uneconomical structural material compared to low self weight of fly ash aggregate concrete. In order to produce concrete of desired density to suit the required application, the self weight of structural and non structural members are to be reduced. Hence economy is achieved in the design of supporting structural elements which lead to the development of light weight concrete. Lightweight concrete is defined as a concrete that has been made lighter than the conventional concrete by changing material composition or production method. Lightweight aggregate concrete is the concrete made by replacing the usual material aggregate by lightweight aggregates. Though lightweight concrete can't always substitute normal concrete for its strength potential, it has its own advantages like reduced dead load, and thus economic structures and enhanced seismic resistance, high sound absorption and good fire resistance. Because of the above reasons the study on fly ash aggregate concrete is taken in this research work.

\section{Materials Used}

The following materials were used for preparing the test specimens

i) Ordinary Portland cement 43 grade confirming to IS:8112-1989

ii) Fly ash (FA) obtained from Thermal power plant, Mettur confirming to IS:3812-1981 
Iii) Local river sand confirming to Grading Zone II of IS: 383-1970

iv) Fly ash Fine Aggregate (FAFA) obtained from cement fly ash proportions 10:90, 12.5:87.5, 15:85, 17.5:82.5, 20:80 and 22.5:77.5.

v) Hard Broken Granite stone (HBG) confirming to graded aggregate of size 20mm as per IS: $383-1970$

Vi) Fly ash Coarse Aggregates (FACA) obtained from cement fly ash proportion 10:90,12.5:87.5,15:85,17.5:77.5,20:80 and 22.5:77.5

vii) Bore well water of MPNMJ Engineering College Campus for mixing and curing of specimens.

\section{Properties of Aggregates}

Table 1. Physical properties of Conventional Fine Aggregate (CFA) and Fly ash fine aggregate (FAFA)

\begin{tabular}{|c|l|l|l|}
\hline S. No & \multicolumn{1}{|c|}{ Properties } & \multicolumn{1}{|c|}{ CFA } & (FAFA) \\
\hline 1 & $\begin{array}{l}\text { Specific } \\
\text { gravity }\end{array}$ & 2.70 & 1.28 \\
\hline 2 & $\begin{array}{l}\text { Bulk density } \\
\left(\mathrm{Kg} / \mathrm{m}^{3}\right)\end{array}$ & 1808 & 838 \\
\hline 3 & Size $(\mathrm{mm})$ & Below 4.75 & Below 4.75 \\
\hline 4 & $\begin{array}{l}\text { Fineness } \\
\text { modulus }\end{array}$ & 2.68 & 2.70 \\
\hline
\end{tabular}

Table 2. Physical properties of Conventional Coarse Aggregate (CCA) and Fly ash Coarse Aggregate (FACA)

\begin{tabular}{|c|c|c|c|}
\hline S. No & Properties & $\mathrm{CCA}$ & FACA \\
\hline 1 & Shape & Angular & Spherical \\
\hline 2 & $\begin{array}{l}\text { Specific } \\
\text { gravity }\end{array}$ & 2.75 & 1.3 \\
\hline 3 & $\begin{array}{l}\text { Bulk density } \\
\left(\mathrm{Kg} / \mathrm{m}^{3}\right)\end{array}$ & 1685 & 913 \\
\hline 4 & Size $(\mathrm{mm})$ & $\begin{array}{l}4.75 \mathrm{~mm} \text { to } \\
20 \mathrm{~mm}\end{array}$ & $\begin{array}{l}4.75 \mathrm{~mm} \text { to } \\
20 \mathrm{~mm}\end{array}$ \\
\hline 5 & $\begin{array}{l}\text { Crushing value } \\
(\%)\end{array}$ & 24.94 & 25.6 \\
\hline 6 & $\begin{array}{l}\text { Impact Value } \\
(\%)\end{array}$ & 23.86 & 21.6 \\
\hline
\end{tabular}


Table 3. Fly Ash (Class F) at Mettur Thermal Power Station (MTPS) Fly ash (Class F) obtained from Mettur Thermal Power Station (MTPS) was used in the experimental work. The comparison of chemical composition of fly ash produced at MTPS to that of world's standard is as below.

\begin{tabular}{|c|c|c|c|}
\hline \multicolumn{4}{|c|}{ Chemical Composition } \\
\hline \multicolumn{2}{|c|}{ Constituent } & \multirow{2}{*}{ 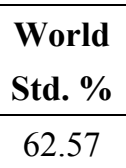 } & \multirow{2}{*}{$\begin{array}{c}\text { Fly ash used in } \\
\text { thesis work \% } \\
54.92 \\
\end{array}$} \\
\hline Silica & $\mathrm{SiO}_{2}$ & & \\
\hline Alumina & $\mathrm{Al}_{2} \mathrm{O}_{3}$ & 31.45 & 23.04 \\
\hline Ferric Oxide & $\mathrm{Fe} 2 \mathrm{O}_{3}$ & 1.87 & - \\
\hline $\begin{array}{l}\text { Titanium } \\
\text { Dioxide }\end{array}$ & $\mathrm{TiO}_{2}$ & 1.45 & - \\
\hline $\begin{array}{l}\text { Manganese } \\
\text { Oxide }\end{array}$ & $\mathrm{MnO}$ & 0.005 & - \\
\hline Calcium Oxide & $\mathrm{CaO}$ & 0.40 & 3.84 \\
\hline $\begin{array}{l}\text { Magnesium } \\
\text { Oxide }\end{array}$ & $\mathrm{MgO}$ & 0.38 & 2.82 \\
\hline Sodium Oxide & $\mathrm{Na}_{2} \mathrm{O}$ & 0.05 & - \\
\hline Potassium Oxide & $\mathrm{K}_{2} \mathrm{O}$ & 0.82 & - \\
\hline Iron & $\mathrm{FE}_{2} \mathrm{O}$ & - & 6.62 \\
\hline Phosphorus & $\mathrm{P}_{2} \mathrm{O}_{5}$ & - & 0.30 \\
\hline $\begin{array}{l}\text { Alkalimetal's } \\
\text { Oxide }\end{array}$ & & - & 2.70 \\
\hline Sulphur & $\mathrm{SO}_{3}$ & - & 0.76 \\
\hline Magnesium & Mgo & - & 2.82 \\
\hline Loss on Ignition & LOI & 1.0 & 2.88 \\
\hline
\end{tabular}

Table 4. Comparison of Workability of FAAC with Conventional Concrete

\begin{tabular}{|c|c|c|c|c|}
\hline \multirow{2}{*}{ 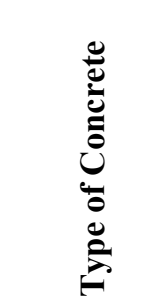 } & \multicolumn{4}{|c|}{ Workability Test } \\
\hline & $\underset{\Xi}{\stackrel{\Xi}{\Xi}}$ & 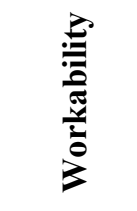 & 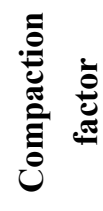 & 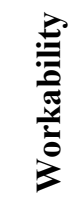 \\
\hline $\begin{array}{l}\text { Control } \\
\text { concrete }\end{array}$ & 40 & Medium & 0.91 & High \\
\hline $\begin{array}{l}\text { Fly ash } \\
\text { aggregate } \\
\text { concrete }\end{array}$ & 60 & Medium & 0.9 & High \\
\hline
\end{tabular}




\section{Formation of Fly Ash Aggregates}

The constituents like cement, fly ash and water produce the fly ash aggregates. Water is the binding material that paves the way for the function of the aggregate with good bond property.

\section{Proportions for Fly Ash Aggregates}

Cement and fly ash are constituents for preparation of the aggregates. Also water is the binder when it is added to increase the workability. Six different proportions of cement and fly ash such as 10:90, 12.5:87.5, 15:85, 17.5:82.5, 20:80 and 22.5:77.5 were tried.

\section{Preparation of Fly Ash Aggregates}

Cement and fly ash were mixed in above six proportions in a concrete mixer. Water was added to the mix by adopting the water cement ratio of 0.3 . The contents were thoroughly mixed in the drum until the complete formation of fly ash aggregates. This method of formation of fly ash aggregates is called pelletisation. The fly ash aggregates are shown in figure 1.

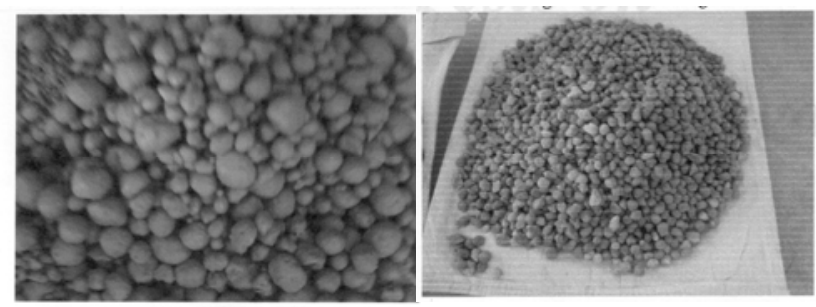

Figure 1. Fly ash Aggregates

\section{Drying and Curing of Fly Ash Aggregates}

The fly ash aggregates were taken out from the mixer and allowed to dry for a day. Then the aggregates were cured in a water tank for 7 days.

\section{Segregation of Fly Ash Aggregates}

After curing, they were segregated into fine and coarse aggregates based on size of pellets as shown in figure 2 . The aggregates having size less than $4.75 \mathrm{~mm}$ were sieved as fine aggregates and size more than $4.75 \mathrm{~mm}$ were sieved as coarse aggregate. From them $20 \mathrm{~mm}$ size coarse aggregates were sieved separately to use them as coarse aggregates.

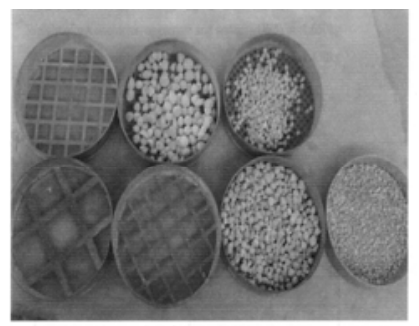

Figure 2. Segregation of fly ash aggregates

\section{Mix Proportions}

Mix design for M20 grade concrete was done by using IS method. As per the design, the mix proportion is 1:1.53:2.68:0.5.

\section{Casting of Test Specimens}

The Concrete Cubes (control specimens) of size $15 \mathrm{~cm} \times 15 \mathrm{~cm} \times 15 \mathrm{~cm}$ were cast by using conventional fine aggregate (CFA) and conventional coarse aggregate (CCA) and using fly ash fine and fly ash coarse aggregates obtained from the above six cement fly ash proportions. The specimens were demoulded after 1 day and immersed in water for 1, 3, 7, 14, 28, 56 and 90days for curing.

Similarly 3 fly ash concrete cubes each were cast using fly ash aggregates obtained from cement fly ash proportions $12.5: 87.5,15: 85,17.5: 82.5,20: 80$ and 22.5:77.5 for different days of curing. 
The concrete cylinders (Control Specimens) of diameter $15 \mathrm{~cm}$ and height $30 \mathrm{~cm}$ were cast by using conventional fine aggregate (CFA) and conventional coarse Aggregate (CCA). For FAAC, the specimens were cast with fly ash fine aggregates (FAFA) and fly ash coarse aggregates (FACA) obtained from the above six cement fly ash proportions. The specimens were demoulded after 1 day and immersed in water for 7 days and 28 days for curing.

Similarly 3 fly ash concrete cylinders were cast using fly ash aggregates obtained from cement fly ash proportions 12.5:87.5, 15:85, 17.5:82.5, 20:80 and 22.5:77.5 for ages of concrete 7 days and 28 days curing.

The concrete beams of (control specimens) of size $100 \mathrm{mmX} 100 \mathrm{mmX} 500 \mathrm{~mm}$ were cast using conventional fine aggregate (CFA) and conventional coarse aggregate (CCA). For FAAC, the specimens were cast with fly ash fine aggregates (FAFA) and fly ash coarse aggregates (FACA) obtained from the above six cement fly ash proportions. The specimens were demoulded after 1 day and immersed in water for 7 days and 28 days for curing.

Similarly 3 fly ash concrete beams were cast using fly ash aggregates obtained from cement fly ash proportions 12.5:87.5, 15:85, 17.5:82.5, 20:80 and 22.5:77.5 for ages of concrete 7 days and 28 days.

\section{Compression Test}

$15 \mathrm{~cm} \times 15 \mathrm{~cm} \times 15 \mathrm{~cm}$ concrete cubes were tested as per IS 516-1959. The test was conducted in $120 \mathrm{~T}$ compression testing machine. The load was applied at the rate approximately $140 \mathrm{~kg} / \mathrm{cm}^{2} / \mathrm{min}$ until the failure of the specimen. The maximum load applied to the specimen until failure was recorded and shown in Table -5 .

Table 5. Compressive strength of fly ash aggregate concrete and control concrete with different ages of testing

\begin{tabular}{|c|c|c|}
\hline $\begin{array}{l}\text { Age of } \\
\text { testing }\end{array}$ & $\begin{array}{c}\text { Proportion } \\
\text { Cement : Fly } \\
\text { ash } \\
\end{array}$ & $\begin{array}{l}\text { Compressive Strength in } \\
\qquad \mathrm{N} / \mathbf{m m}^{2}\end{array}$ \\
\hline \multirow{7}{*}{1 day } & $10: 90$ & 2.62 \\
\hline & $12.5: 87.5$ & 2.76 \\
\hline & $15: 85$ & 3.84 \\
\hline & $17.5: 82.5$ & 2.57 \\
\hline & $20: 80$ & 2.21 \\
\hline & $22.5: 77.5$ & 2.13 \\
\hline & $\begin{array}{l}\text { Control } \\
\text { concrete }\end{array}$ & 3.33 \\
\hline \multirow{7}{*}{3 days } & $10: 90$ & 6.41 \\
\hline & $12.5: 87.5$ & 6.55 \\
\hline & $15: 85$ & 9.43 \\
\hline & $17.5: 82.5$ & 6.81 \\
\hline & $20: 80$ & 6.61 \\
\hline & $22.5: 77.5$ & 6.28 \\
\hline & $\begin{array}{l}\text { Control } \\
\text { concrete }\end{array}$ & 8.37 \\
\hline \multirow{7}{*}{7 days } & $10: 90$ & 11.62 \\
\hline & $12.5: 87.5$ & 12.89 \\
\hline & $15: 85$ & 15.93 \\
\hline & $17.5: 82.5$ & 13.10 \\
\hline & $20: 80$ & 12.90 \\
\hline & $22.5: 77.5$ & 10.24 \\
\hline & Control & 14.34 \\
\hline
\end{tabular}




\begin{tabular}{|c|c|c|}
\hline & concrete & \\
\hline \multirow{7}{*}{14 days } & $10: 90$ & 14.20 \\
\hline & $12.5: 87.5$ & 15.60 \\
\hline & $15: 85$ & 20.24 \\
\hline & $17.5: 82.5$ & 16.20 \\
\hline & $20: 80$ & 15.80 \\
\hline & $22.5: 77.5$ & 12.60 \\
\hline & $\begin{array}{l}\text { Control } \\
\text { concrete }\end{array}$ & 17.62 \\
\hline \multirow{7}{*}{28 days } & $10: 90$ & 16.30 \\
\hline & $12.5: 87.5$ & 17.23 \\
\hline & $15: 85$ & 23.71 \\
\hline & $17.5: 82.5$ & 17.90 \\
\hline & $20: 80$ & 17.20 \\
\hline & $22.5: 77.5$ & 14.80 \\
\hline & $\begin{array}{l}\text { Control } \\
\text { concrete }\end{array}$ & 20.80 \\
\hline \multirow{7}{*}{56 days } & $10: 90$ & 17.12 \\
\hline & $12.5: 87.5$ & 18.26 \\
\hline & $15: 85$ & 25.35 \\
\hline & $17.5: 82.5$ & 19.20 \\
\hline & $20: 80$ & 18.32 \\
\hline & $22.5: 77.5$ & 16.19 \\
\hline & $\begin{array}{l}\text { Control } \\
\text { concrete }\end{array}$ & 22.44 \\
\hline \multirow{7}{*}{90 days } & $10: 90$ & 19.10 \\
\hline & $12.5: 87.5$ & 19.40 \\
\hline & $15: 85$ & 27.03 \\
\hline & $17.5: 82.5$ & 20.18 \\
\hline & $20: 80$ & 19.54 \\
\hline & $22.5: 77.5$ & 18.64 \\
\hline & $\begin{array}{l}\text { Control } \\
\text { concrete }\end{array}$ & 24.96 \\
\hline
\end{tabular}

Fly ash aggregate concrete with fly ash aggregates prepared from cement fly ash proportions 15:85 showed 15\%, $13 \%, 11 \%, 15 \%, 14 \%, 13 \%$ and $8 \%$ increase in Compressive strength at the ages of 1 day, 3days, 7 days, 14 days, 28days, 56days and 90days respectively over the control concrete.

Fly ash aggregate concrete with fly ash aggregates prepared from other cement fly ash proportions 10:90, $12.5: 87.5,17.5: 82.5,20: 80$ and 22.5:77.5 showed reduction in compressive strength at the ages of 1day, 3days, 7days, 14days, 28days, 56days and 90days respectively over control concrete.

\subsection{Development of Strength compared with respective 28days Compressive Strength}

The strength development of control concrete compared with its corresponding 28 days strength are $16 \%, 40 \%$, $69 \%, 85 \%, 108 \%$ and $120 \%$ for $1,3,7,14,56$ and 90 days respectively. 
The strength development of fly ash aggregate concrete with aggregates made from cement fly ash proportion 10:90 compared with its corresponding 28days strength are $16 \%, 39 \%, 71 \%, 87 \%, 105 \%$ and $117 \%$ for $1,3,7,14$, 56 and 90days respectively.

The strength gain for fly ash aggregate concrete with fly ash aggregates made from cement fly ash proportion 12.5:87.5 compared with its corresponding 28 days strength are $16 \%, 38 \%, 75 \%, 91 \%, 106 \%$ and $113 \%$ for 1,3 , 7, 14, 56 and 90days respectively.

The strength gain for fly ash aggregate concrete with fly ash aggregates made from cement fly ash proportion 15:85 compared with its corresponding 28days compressive strength are $16 \%, 40 \%, 67 \%, 85 \%, 106 \%$ and $114 \%$ at the age of $1,3,7,14,56$ and 90days respectively.

The compressive strength gain at the ages of 1, 3, 7, 14, 56 and 90days for the fly ash aggregate concrete with fly ash aggregates made using cement fly ash proportion $17.5: 82.5$ are $14 \%, 38 \%, 73 \%, 91 \%, 107 \%$ and $113 \%$ respectively.

The strength gain for the fly ash aggregate concrete containing fly ash aggregates made by using cement fly ash proportion 20:80 showed the compressive strength at 1, 3, 7, 14, 56 and 90days were 13\%, 38\%, 75\%, 92\%, $107 \%$ and $114 \%$ respectively when compared to its 28 days strength.

When comparing the strength gain at 28days of fly ash aggregate concrete with fly ash aggregates obtained from cement fly ash proportion $22.5: 77.5$ was $23 \%, 42 \%, 69 \%, 85 \%, 109 \%$, and $126 \%$ at the ages of $1,3,7,14,56$ and 90days respectively.

\section{Split Tension Test}

Concrete cylinders of $15 \mathrm{~cm}$ diameter and $30 \mathrm{~cm}$ height were tested for Split tensile strength as per IS 5816-1976. The specimen was placed horizontally between the loading surfaces of the compression testing machine and the load was applied without shock until the failure of the specimen. The maximum load at failure was tabulated in Table -6 .

Table 6. Split tensile strength of fly ash aggregate concrete and control concrete with different ages of testing

\begin{tabular}{|c|c|c|}
\hline $\begin{array}{l}\text { Age of } \\
\text { testing }\end{array}$ & $\begin{array}{c}\text { Proportion } \\
\text { Cement : Fly ash }\end{array}$ & $\begin{array}{l}\text { Splitting tensile } \\
\text { Strength in } \\
\mathrm{N} / \mathbf{m m}^{2}\end{array}$ \\
\hline \multirow{7}{*}{7 days } & 10:90 & 3.15 \\
\hline & $12.5: 87.5$ & 3.45 \\
\hline & $15: 85$ & 4.60 \\
\hline & $17.5: 82.5$ & 3.20 \\
\hline & $20: 80$ & 3.05 \\
\hline & $22.5: 77.5$ & 2.95 \\
\hline & Control concrete & 4.10 \\
\hline \multirow{7}{*}{28 days } & 10:90 & 3.70 \\
\hline & $12.5: 87.5$ & 4.10 \\
\hline & $15: 85$ & 5.56 \\
\hline & $17.5: 82.5$ & 3.90 \\
\hline & $20: 80$ & 3.65 \\
\hline & $22.5: 77.5$ & 3.20 \\
\hline & Control concrete & 4.84 \\
\hline
\end{tabular}

The fly ash aggregate concrete beam with fly ash aggregate made from cement fly ash proportion 15:85 showed an increase in split tensile strength of $12 \%$ and $15 \%$ respectively at the ages of 7 days and 28 days compared with control concrete beam. 
The cement fly ash proportions of 10:90, 12.5:87.5, 17.5:82.5, 20:80 and 22.5:77.5 showed reduction in split tensile strength of $35 \%, 16 \%, 22 \%, 26 \%$, and $28 \%$, respectively at the age of curing in 7 days and $24 \%, 15 \%$, $19 \%, 25 \%$, and $34 \%$, respectively at the age of curing in 28 days than control concrete specimen.

\section{Flexural Strength Test}

The concrete beams of size $10 \mathrm{~cm}$ x $10 \mathrm{~cm}$ x $50 \mathrm{~cm}$ were tested as per IS 516-1959. The load was applied through two similar rollers mounted at one third points of the supporting span. The load was applied without shock until the failure occurs. The maximum load at failure was tabulated in Table -7 .

Table 7. Flexural strength of fly ash aggregate concrete and control concrete with different ages of testing

\begin{tabular}{|c|c|c|}
\hline $\begin{array}{l}\text { Age of } \\
\text { testing }\end{array}$ & $\begin{array}{c}\text { Proportion } \\
\text { Cement : Fly ash }\end{array}$ & $\begin{array}{c}\text { Flexural Strength } \\
\text { in } \\
\mathrm{N} / \mathbf{m m}^{2}\end{array}$ \\
\hline \multirow{7}{*}{7 days } & $10: 90$ & 4.10 \\
\hline & $12.5: 87.5$ & 4.50 \\
\hline & $15: 85$ & 5.49 \\
\hline & $17.5: 82.5$ & 4.40 \\
\hline & $20: 80$ & 4.20 \\
\hline & $22.5: 77.5$ & 3.95 \\
\hline & Control concrete & 4.95 \\
\hline \multirow{7}{*}{28 days } & $10: 90$ & 4.40 \\
\hline & $12.5: 87.5$ & 4.75 \\
\hline & $15: 85$ & 6.22 \\
\hline & $17.5: 82.5$ & 4.60 \\
\hline & $20: 80$ & 4.35 \\
\hline & $22.5: 77.5$ & 4.15 \\
\hline & Control concrete & 5.36 \\
\hline
\end{tabular}

The fly ash aggregate concrete containing fly ash aggregate made from cement fly ash proportion 15:85 showed increase in flexural strength of $11 \%$ and $16 \%$ respectively at the ages of curing in 7 days and 28 days than the control concrete specimen.

The cement fly ash proportions 10:90, 12.5:87.5, 17.5:82.5, 20:80 and 22.5:77.5 showed reduction in flexural strength of $17 \%, 9 \%, 11 \%, 15 \%$, and $20 \%$, respectively at the age of curing in 7 days and $18 \%, 11 \%, 14 \%, 18 \%$, and $23 \%$, respectively at the age of curing in 28 days than control concrete specimen.

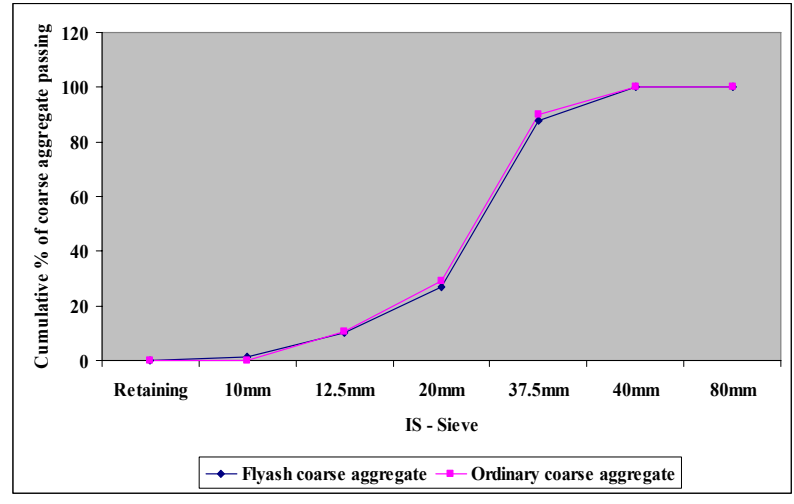

Figure 3(a). Grading curves for conventional coarse aggregate and fly ash coarse aggregate 


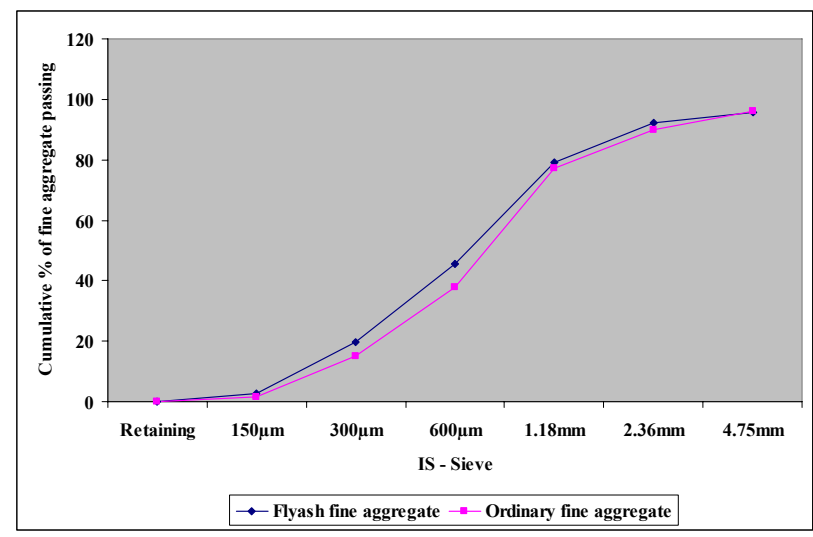

Figure 3 (b). Grading curves for conventional fine aggregate and fly ash fine aggregate

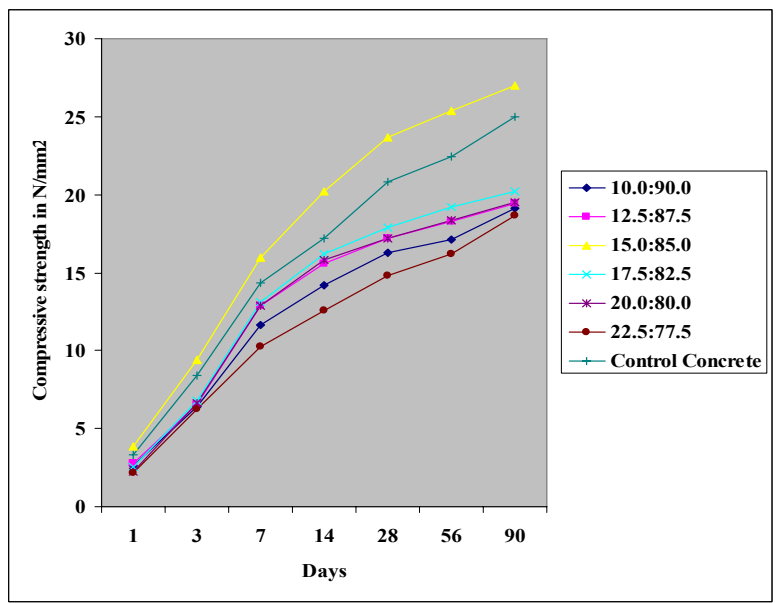

Figure 4. Comparison of Compressive strength of fly ash aggregate concrete and control concrete vs Number of days of curing

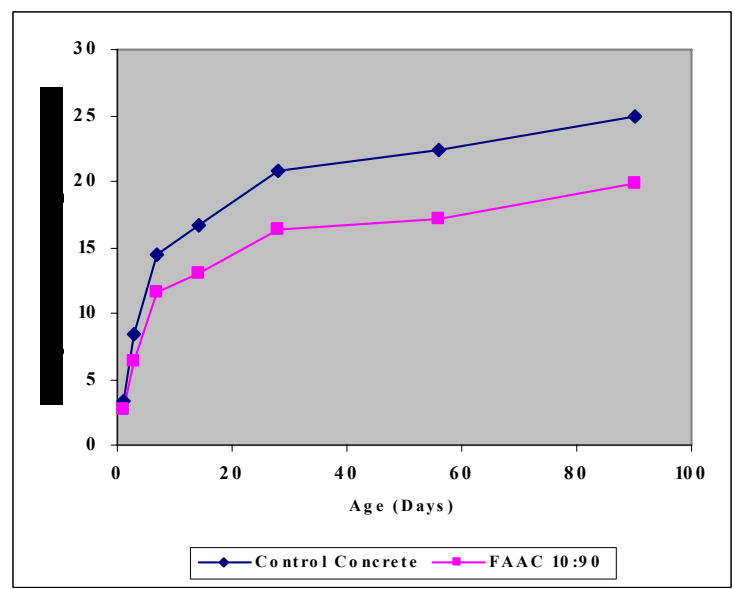

Figure 5. Comparison of compressive strength of control concrete and FAAC with FAA obtained from cement fly ash proportion 10:90 vs Number of days of curing 


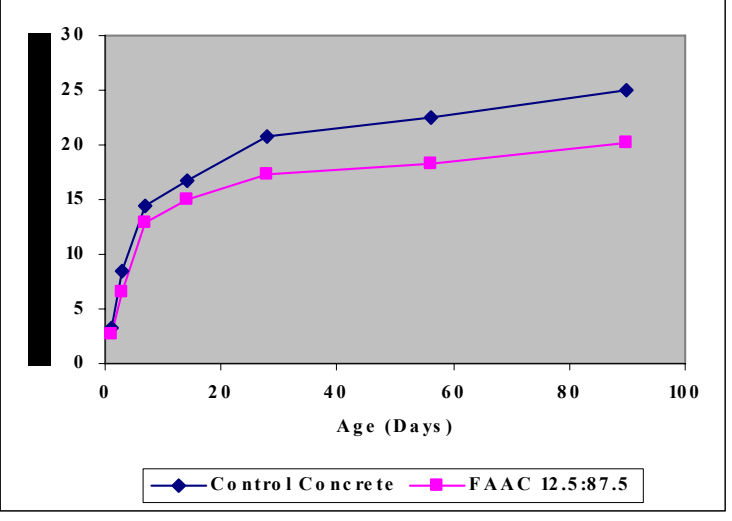

Figure 6. Comparison of compressive strength of control concrete and FAAC with FAA obtained from cement fly ash proportion 12.5:87.5 vs Number of days of curing

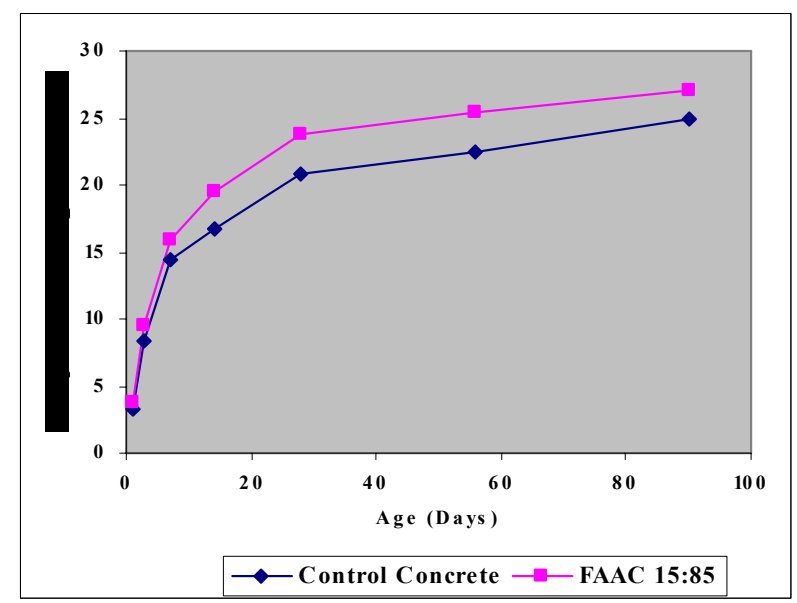

Figure 7. Comparison of compressive strength of control concrete and FAAC with FAA obtained from cement fly ash proportion 15:85 vs Number of days of curing

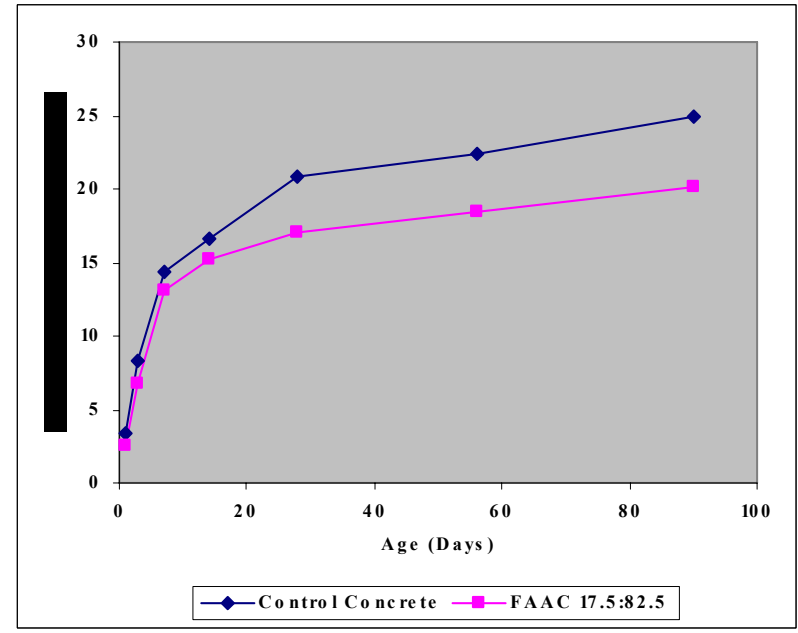

Figure 8. Comparison of compressive strength of control concrete and FAAC with FAA obtained from cement fly ash proportion 17.5:82.5 vs Number of days of curing 


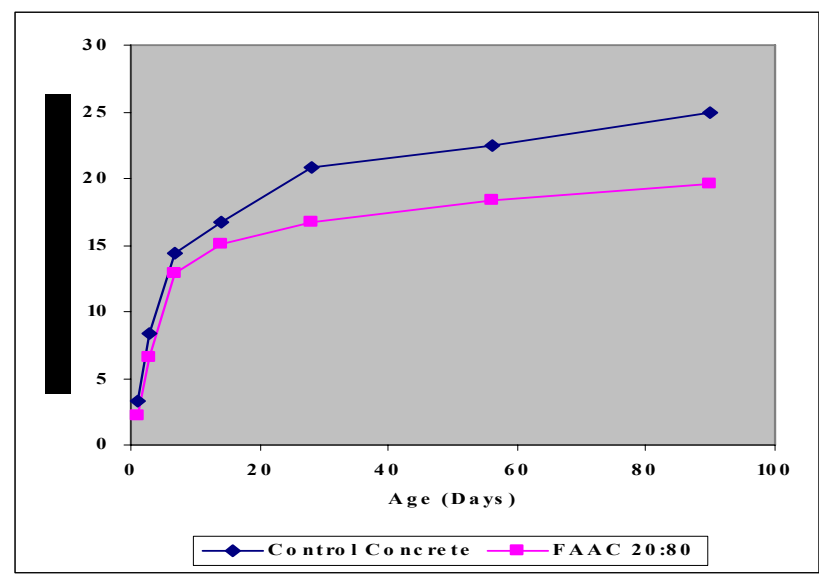

Figure 9. Comparison of compressive strength of control concrete and FAAC with FAA obtained from cement fly ash proportion 20:80 vs Number of days of curing

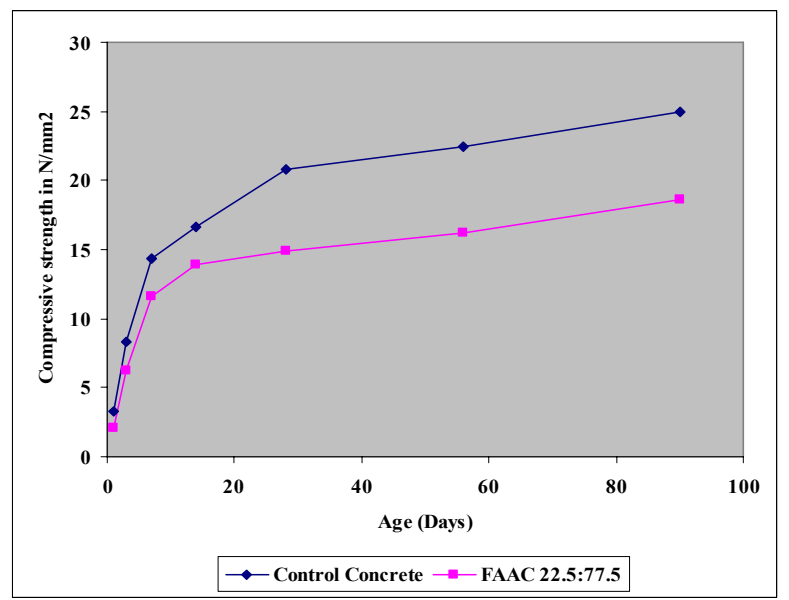

Figure 10. Comparison of compressive strength of control concrete and FAAC with FAA obtained from cement fly ash proportion 22.5:77.5 vs Number of days of curing

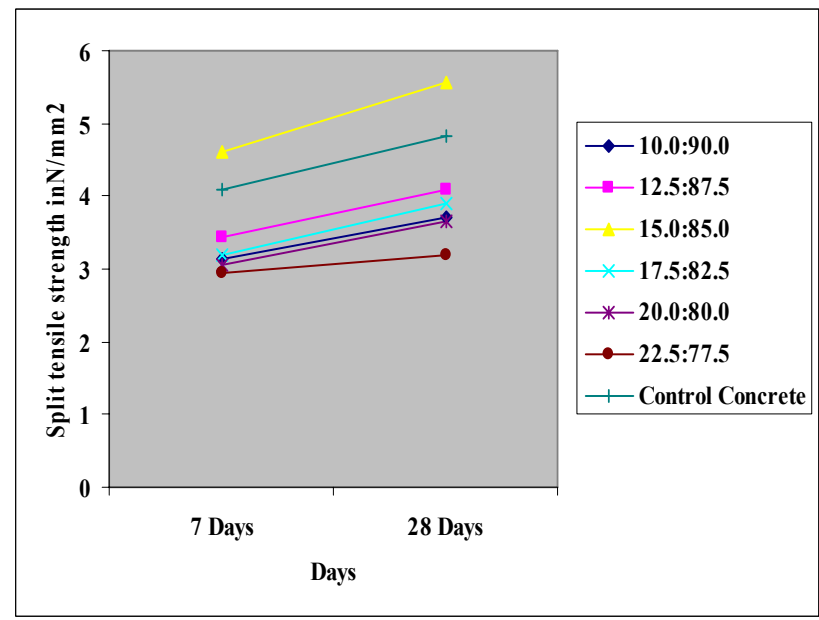

Figure 11. Comparison of Split Tensile strength of fly ash aggregate concrete and control concrete vs Number of days of curing 


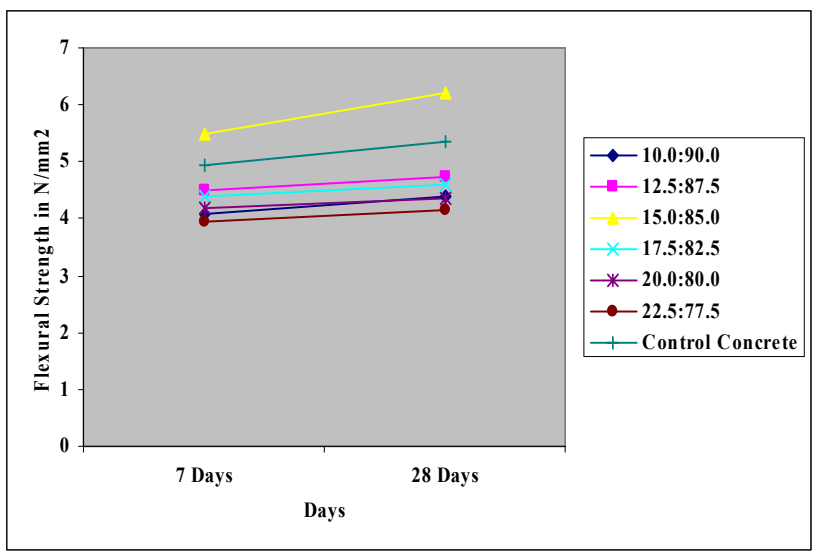

Figure 12. Comparison of Flexural strength of fly ash aggregate concrete and control concrete vs Number of

\section{Conclusions}

days of curing

$>\quad$ From the experimental investigation, it was found that the compressive strength was increased for fly ash aggregate concrete cubes with cement fly ash proportion 15:85, when compared to the control concrete cubes at all the ages of curing.

The fly ash aggregate concrete cubes containing fly ash aggregates made using cement fly ash proportions 10:90, 12.5:87.5, 17.5:82.5, 20:80 and 22.5:77.5 showed reduction in compressive strength when compared to the control concrete at all the ages.

$>\quad$ The split tensile strength of fly ash aggregate concrete beams with fly ash aggregates of cement fly ash proportion 15:85 was increased when compared to the control concrete beams at all the ages of 7 days and 28days of curing.

$>\quad$ The reduction in split tensile strength of FAAC specimen made with FAA of cement fly ash proportions 10:90, 12.5:87.5, 17.5:82.5, 20:80 and 22.5:77.5 while comparing the control concrete specimens at all the ages of 7 days and 28 days of curing.

The increase in flexural strength of the specimen was observed for the fly ash aggregate concrete containing fly ash aggregates made using cement fly ash proportion 15:85 when compared to the control concrete at the ages of 7 days and 28 days of curing.

$>\quad$ The specimen made with FAA of cement fly ash proportions 10:90, 12.5:87.5, 17.5:82.5, 20:80 and 22.5:77.5 showed the reduction in flexural strength of fly ash aggregate concrete over the control concrete at the ages of 7 days and 28 days.

$>\quad$ The aggregates are vital elements in concrete. The usage of enormous quantities of aggregates results in destruction of hills causing geological and environmental imbalance.

The environmental impacts of extracting river sand and crushed stone aggregates become a source of increasing concern in most parts of the Country. Pollution hazards, noise, dust, blasting vibrations, loss of forests and spoiling of natural environment are the bad impacts caused due to extraction of aggregates. Landslides of weak and steep hill slopes are induced due to unplanned exploitation of rocks.

Considering the depletion of natural sources and the effect on environment, the disposal problems involved in disposing fly ash, light weight characteristics of fly ash aggregates with good mechanical properties (Compression strength, Split Tension strength and Flexural strength) as seen in the above investigation, a particular attention may be focused on the usage of fly ash aggregates in concrete.

\section{Acknowledgement}

The authors express their sincere thanks to the Correspondent of MPNMJ Engineering College, Chennimalai, Erode District for the support he has provided to carry out this experimental investigation.

\section{Literature Review}

N.P.Rajamani and P.S. Ambily, scientist, SERC, Chennai carried out the research work on "Selection of mortar for light weight aggregate concrete made with fly ash based aggregate". They concluded that conversion of fly 
ash with aggregate is technically feasible and are found to be light weight in nature. They found fly ash aggregate concrete up to $20 \mathrm{Mpa}$ can be used for production of concrete blocks for masonry construction in structures. They also suggested to select mortar which can produce fly ash aggregate concrete of strength up to 40Mpa. However concrete strengths more than 40Mpa can also be produced using less content of fly ash aggregates.

Dr.J.B.Behera, Dr.B.D.Nayak, Dr.H.S.Ray and Dr.B.Sarangi examined the use of sintered fly ash aggregate in concrete as a partial replacement of granite aggregate. They concluded that in addition to light weight characteristics, the sintered fly ash concrete possesses strength and deformation characteristics similar to concrete with natural granite aggregate.

Gao Li-Xiong, Yaoyan and Wang Ling, China building materials Academy, Beijing found light weight aggregate concrete made with sintered fly ash aggregate showed good workability, high compressive strength and low absorption of water.

Mehnet Gesoglu, Turan Ozturan and Erhan Gunegisi found the compressive strength of concrete ranging from 20 to 50Mpa was practically produced by using light weight fly ash aggregates. They also found the increase in splitting tensile strength of concrete due to increase in aggregate crushing strength of fly ash aggregates.

Haydar Arsian and Gokhan Baykal investigated the fly ash aggregates produced from fly ash and cement mixing by pelletization method and evaluated Engineering properties such as crushing strength, specific gravity, water absorption, particle size distribution, surface characteristics and shear strength properties of the manufactured aggregates experimentally. The experimental investigation showed that these aggregates are a good alternative for wide range of civil Engineering applications.

Rudolph Klotten, Metallurgical Engineer, Bakerstown road, Tarentum expressed that the largest potential outlet for light weight aggregates(LWA) manufactured from fly ash is in concrete, concrete products, block and masonry units. LWA offer better thermal and acoustical insulation, high fire resistance, easy cutting and drilling.

Gokhan Baykal and ATA Gurhan Doven studied the properties of fly ash aggregates made by pelletization process such as unit weight, specific gravity, water absorption, crushing value test, California bearing ratio (CBR), Direct shear tests, soundness tests, compressive and flexural strength and obtained good results when compared to conventional aggregates in concrete.

\section{References}

Byung-Wan Jo, Seung-Kook Park and Jang-Bin Park. (2006). "Properties of concrete made with alkali activated fly ash light weight aggregate", Cement and Concrete composites (2006), PP 1 to 8.

Dr. J.P. Behera, Dr. H.S. Ray, Dr. B.D. Nayak and Dr. B. Sarangi. (2004). "Light weight concrete with sintered fly ash aggregates". A study on partial replacement to normal granite aggregate. Institution of Engineers, India (IE(I)) Journal - CV Vol 85 August'2004, PP 84 to 87.

Gao Li-Xiang, Yao Yan and Wang Ling. "Research on sintered fly ash aggregate of high strength and low absorption of water", Proceedings of International workshop on Sustainable development and Concrete Technology, PP 151 to 157.

Gokhan Banjkal, Ata Gurhan Doren. (2000). "Utilisation of fly ash by pelletization process", application of areas and research results, resources, conservation and recycling 30 (2000), PP 59 to 77.

IS 10262-1982 recommended guide lines for concrete mix design.

M.S.Shetty. (2005). ” Concrete Technology”, S.Chand and Co Publishing Company, pp 53 to 62.

Mehmet Gesoglu, Turen Oztumn and Guneyisi(2006), "Effects of cold bonded fly ash aggregate properties on the shrinkage cracking of light weight concretes", cement and concrete composites 28(2006) PP 592 - 605.

Neville A.M. (1995). "Properties of concrete", IV Ed Longman, 824p.

P.Kumar Mehta and Paulo J.M.Monteiro. "Concrete Miscrostructure, Properties and Materials" pp 226 to 230

Rajamani N.P, Annie peter J. , Sabitha D. and Gopalakrishanan S. (2004). " Studies on development on bonded fly ash aggregates for use as coarse aggregate in structural grade concretes" New building materials and construction world Vol 10,issue 4, Oct (pp 60 to 70).

Rajamani N.P and Ambily P.S. (2006). "Selection of mortar for light weight aggregate concrete made with fly ash based aggregate", New building materials and construction world journal June 2006(pp : 80 to 88) August 2006. 
Tommy Y. Lo and H.Z. Cui. "Properties of green light weight aggregate concrete" proceedings of International workshop on sustainable development and Concrete Technology PP113 to 118. 